\title{
Factors Influencing Meat Buying Behaviour among Rural, Semi-Urban and Urban Households
}

\author{
T. Senthilkumar ${ }^{1}$, V. Muralidhar ${ }^{2}$ \\ ${ }^{1}$ Associate Professor, Directorate of Extension Education, Tamil Nadu Veterinary and Animal Sciences University, \\ Chennai - 600 051, India \\ ${ }^{2}$ Veterinary Officer and Corresponding author, Mandya, Karnataka, India
}

\begin{abstract}
The worldwide meat consumption has attracted much attention not only for nutritionists but also agricultural and food economists in recent years. Studies showed that urbanization has been carrying a rise in demand for meat products. In India, cultural differences are also accountable for variations in meat consumption patterns. A study was performed to ascertain the preferences of consumers towards meat consumption among the rural, semi-urban and urban households of Karnataka with sample size of 90 meat eating respondents and 30 non-meat eating respondents. The results showed that 'flavour' and 'taste' of the meat had a very good influence on meat consumption among all the locations.
\end{abstract}

Keywords: meat consumption, consumers, preference, households

\section{Introduction}

In developing countries, culture plays a crucial role in determining food patterns. As Indians, are controlled by the traditions and customs, the dietary habit is significantly influenced. In Indian context, culture, traditions, customs and taboos influence meat consumption to a great extent especially in the rural societies. However, studies showed that urbanization has been causing a rise in demand for meat products. As people move to cities, they adapt to get into meat consumption. The difference in consumption and production methods correlates strongly with the overall economy of a country. India is the country that consumes the least meat per capita (Tepper, 2012). The differences in food consumption exists across regions, states and in demographic situations. There is also a vast variation in the per capita consumption of meat and livestock products across the states, regions and in living situations like rural, semi-urban and urban areas (Gandhi and Zhou, 2010).

The study was therefore undertaken to assess the meat consumption behaviour among the rural, semi-urban and urban community by collecting information from the meat consumers on demographical parameters and consumer preferences.

\section{Methodology}

A total of 90 meat consuming respondents were selected randomly from Belgaum district, Bangalore rural district and Bangalore city representing the rural, semi-urban and urban locations respectively. The factors influencing the meat buying behaviour of the consumer in the present referred to taste, texture, freshness, colour, odour, flavour, shopping environment availability, price, nutritive value, safety and quality factors of meat. Interview method was followed for data collection and the Garrett's ranking techniques was adopted for the present study. The respondents were asked to rank each factor. The order of merit thus given by the respondents was converted into per cent position by using the following formula.

\author{
Per cent position $=100\left(\mathrm{R}_{\mathrm{ij}}-0.5\right) / \mathrm{N}_{\mathrm{j}}$ \\ Where, $R_{i j}$-Rank given for $i^{\text {th }}$ factor by $j^{\text {th }}$ individual \\ $\mathrm{N}_{\mathrm{j}}$ - Number of factors ranked by $\mathrm{j}^{\text {th }}$ individual.
}

The per cent position for each rank thus obtained was converted into scores by referring to the table given by Garrett and Woodworth (1969). Then the mean scores were calculated for each factor and the appropriate rank was given and interpreted.

\section{Results and Discussion}

The factors influencing the consumption of meat in rural, semi-urban and urban households are presented in the below Table.

Factors influencing the meat buying behaviour of consumers

\begin{tabular}{|c|c|c|c|c|c|c|}
\hline \multirow{3}{*}{ Factors } & \multicolumn{6}{|c|}{ Meat consuming respondents } \\
\hline & \multicolumn{2}{|c|}{$\begin{array}{c}\text { Rural } \\
\text { households } \\
(\mathrm{n}=30)\end{array}$} & \multicolumn{2}{|c|}{$\begin{array}{l}\text { Semi-urban } \\
\text { households } \\
(\mathrm{n}=30)\end{array}$} & \multicolumn{2}{|c|}{$\begin{array}{c}\text { Urban } \\
\text { households } \\
(\mathrm{n}=30)\end{array}$} \\
\hline & $\begin{array}{c}\text { Mean } \\
\text { score }\end{array}$ & Rank & $\begin{array}{l}\text { Mean } \\
\text { score }\end{array}$ & Rank & $\begin{array}{l}\text { Mean } \\
\text { score }\end{array}$ & Rank \\
\hline Taste & 54.73 & II & 59.64 & $\mathrm{I}$ & 60.61 & $\mathrm{I}$ \\
\hline Texture & 49.64 & III & 55.77 & II & 47.95 & VI \\
\hline Freshness & 47.74 & VI & 43.98 & VIII & 52.03 & $\mathrm{~V}$ \\
\hline Colour & 47.86 & $\mathrm{~V}$ & 52.08 & III & 54.76 & III \\
\hline Odour & 41.99 & VIII & 51.03 & $\mathrm{~V}$ & 53.21 & IV \\
\hline Flavour & 60.47 & $\mathrm{I}$ & 51.23 & IV & 56.69 & II \\
\hline $\begin{array}{l}\text { Shopping } \\
\text { environment }\end{array}$ & 39.01 & $\mathrm{X}$ & 39.35 & XII & 47.02 & VII \\
\hline Availability & 46.47 & VII & 44.09 & VII & 42.84 & IX \\
\hline Price & 48.91 & IV & 48.12 & VI & 44.41 & VIII \\
\hline Nutritive value & 41.12 & IX & 41.02 & $\mathrm{XI}$ & 40.11 & $\mathrm{X}$ \\
\hline Safety & 36.66 & XI & 39.93 & $\mathrm{X}$ & 39.10 & $\mathrm{XI}$ \\
\hline Quality & 34.94 & XII & 41.64 & IX & 35.76 & XII \\
\hline
\end{tabular}

In rural areas, among various factors, 'flavour' ranked 'first' with an average mean score of 60.47 which was followed by taste (54.73), texture (49.64), price (48.91), colour (47.86), freshness (47.74), availability (46.47), odour (41.99), nutritive 


\section{International Journal of Science and Research (IJSR) \\ ISSN (Online): 2319-7064 \\ Index Copernicus Value (2013): 6.14 | Impact Factor (2014): 5.611}

value (41.12), shopping environment (39.01) and safety (36.66). The factor 'quality' occupied the 'twelfth rank' with an average mean score of 34.94 .

In semi-urban area, among various factors 'taste' was ranked 'first' with an average mean score of 59.64 which was followed by texture (55.77), colour (52.08), flavour (51.23), odour (51.03), price (48.12), availability (44.09), freshness (43.98), quality (41.64), safety (39.93) and nutritive value (41.02). The factor 'shopping environment' occupied the 'twelfth 'rank' with an average mean score of 39.35 .

In urban area, among various factors, 'taste' was ranked 'first' with an average mean score of 60.61 which was followed by flavour (56.69), colour (54.76), odour (53.21), freshness (52.03), texture (47.95), shopping environment (47.02), price (44.41), availability (42.84), nutritive value (40.11) and safety (39.10). The factor 'quality' occupied the 'twelfth rank' with an average mean score of 35.76.

\section{Conclusion}

The respondents of rural area had indicated that the 'flavour' of meat had high influence among all the factors. Whereas the respondents of semi-urban and urban area indicated that 'taste' of the meat had high influence among all the factors. The factors 'flavour' and 'taste' sensations are found to be influencing the consumption because food items are generally attracted mainly on these two sensational factors. The 'flavour' and 'taste' of the meat had a very good influence on meat consumption among all locations.

\section{References}

[1] Babu, A.J., A.R. Sundari, G. Triveni and J. Indumathi, 2010. Study of meat consumption patterns in rural households of Chittoor District of Andhra Pradesh. Tamilnadu J. Veterinary \& Animal Sciences, 6(4): 183187.

[2] Bahl, S., 2012. Consumer behaviour towards food retailing system. Arth Prabhand: A Journal of economics and Management, 1(4): 39-53.

[3] Deshmukh-Taskar, P., T.A. Nicklas, S.J. Yang and G.S. Berension, 2007. Does food group consumption vary by differences in socioeconomic, demographic, and lifestyle factors in young sdults? The Bogalusa Heart Study. J. Am. Diet Assoc. 107(2): 223-234.

[4] Gandhi, V.P and Z.Y. Zhou, 2010. Rising demand for livestock products in India: Nature, Patterns and Implication. Australasian Agribusiness Review, 18: 103-135.

[5] Garrett, E.H. and R.S. Woodworth, 1969. Statistics in psychology and education. Vakils, Feffer and Simons Pvt. Ltd., Bombay, pp. 329.

[6] Raghavendra, H.N., S.B. Mahajanshetti, N.N. Karnool, V.S. Kulkarni and H. Basavaraj, 2009. Meat consumption pattern and its preference in Dharwad District: A socio- economic analysis. Karnataka $J$. Agric. Sci. 22(2): 353-358.
[7] Reddy, M.S and D.T. Raju, 2010. Meat consumption pattern in Hyderabad city. Indian Journal of Animal Research, 44(4): 248-253.

[8] Tepper, R., 2012. World's meat consumption: Luxembourg eats the most per person, India the least. The Huffington Post.

\section{Author Profile}

Dr. T. Senthilkumar, M.V.Sc., Ph.D., Associate Professor, Directorate of Extension Education, Tamil Nadu Veterinary and Animal Sciences University, Chennai - 600 051, India

Dr. V. Muralidhar, M.V.Sc., Veterinary Officer and Corresponding author, Mandya, Karnataka, India 